\title{
Primary Tupaia Javanica Hepatocyte Culture as an In Vitro Model for Human Hepatitis B Virus Infection
}

\author{
Kemal Fariz Kalista*, Maryati Surya**, Silmi Mariya**, Diah Iskandriati**, \\ Irsan Hasan*, Rino Alvani Gani* \\ *Division of Hepatobiliary, Department of Internal Medicine, Faculty of Medicine, \\ Universitas Indonesia/Dr. Cipto Mangunkusumo National General Hospital, Jakarta \\ ${ }^{* *}$ Primate Research Center, Institut Pertanian Bogor, Bogor
}

\author{
Corresponding author: \\ Kemal Fariz Kalista. Division of Hepatobiliary, Department of Internal Medicine, Dr. Cipto Mangunkusumo \\ National General Hospital. Jl. Diponegoro No. 71 Jakarta. Phone: +62-21-31900924; facsimile: +62-21-3918842. \\ E-mail: kemalfarizkalista@gmail.com
}

\begin{abstract}
Background: Hepatitis B virus (HBV) infection is still one of the biggest health problems in the world, which could lead to chronic hepatitis, cirrhosis and hepatocellular carcinoma. Treatment for HBV infection has not yet achieved a functional cure. More studies are needed to investigate human $H B V(H u H B V)$, but the scarcity of animal models for HuHBV infection became a barrier. Recently, many studies have shown that Tupaia are suitable for the study of HuHBV. The purpose of this study was to develop a primary Tupaia hepatocyte (PTH) culture from T. javanica, a species of Tupaia found in Indonesia, and to prove that HuHBV can replicate in the PTH.

Method: In vitro experimental study using PTH isolated from five wild adult T. javanica in Primate Research Center, IPB University. HuHBV was taken from humans with HBsAg and HBV-DNA (+). PTH cells then were infected with HuHBV after reaching 80\% confluence. Observation on PTH cells was done every day for 20 days. Qualitative and quantitative HBsAg were measured using a CMIA while HBV-DNA and cccDNA were measured by RT-PCR.

Results: A cytopathic effect was seen on day post-infection (DPI)-16. HBsAg and HBV-DNA were detected from DPI-2 until DPI-18, with HBV-DNA level peaked on DPI-12. cccDNA concentration was fluctuating from DPI-2 until DPI-20 with the highest level on DPI-16.

Conclusion: Development of PTH culture from T. javanica showed good result with evidence that HuHBV could replicate in the PTH. This finding supports T. javanica as a potential animal model for HuHBV-related researches.
\end{abstract}

Keywords: hepatitis B virus, primary Tupaia hepatocyte, T. javanica

\begin{abstract}
ABSTRAK
Latar belakang: Infeksi virus Hepatitis B (VHB), masih menjadi salah satu masalah kesehatan terbesar di dunia, yang dapat berkembang menjadi hepatitis kronik, sirosis, dan karsinoma hepatoseluler. Terapi VHB yang ada saat ini belum dapat mencapai functional cure. Penelitian terkait VHB manusia (human HBV, HuHBV), terhalang oleh sedikitnya hewan model yang dapat digunakan. Studi literatur terkini menunjukkan bahwa hewan Tupaia cocok dijadikan sebagai hewan model untuk HuHBV. Penelitian ini bertujuan untuk mengembangkan kultur primer hepatosit (KPH) T. javanica, spesies Tupaia yang ditemukan di Indonesia dan untuk membuktikan bahwa HuHBV dapat bereplikasi pada KPH T. javanica
\end{abstract}


Metode: Penelitian eksperimental in vitro menggunakan kultur primer hepatosit Tupaia dari lima ekor T. javanica dewasa di Pusat Studi Satwa Primata (PSSP) Institut Pertanian Bogor. HuHBV diambil dari manusia dengan HBsAg dan DNA VHB (+), kemudian diinfeksikan ke ke KPH setelah KPH mencapai konfluens 80\%. Observasi dilakukan setiap hari selama 20 hari. HBsAg kualitatif dan kuantitatif diperiksa menggunakan metode CMIA sementara DNA VHB dan cccDNA diukur dengan RT-PCR.

Hasil: Efek sitopatik terlihat pada hari pascainfeksi (HPI-16). HBsAg dan DNA VHB terdeteksi pada HPI-2 sampai HPI-18, dengan kadar DNA VHB tertinggi pada HPI-12. Konsentrasi cccDNA berfluktuasi dari HPI-2 sampai HPI-20 dengan kadar tertinggi pada HPI-16.

Simpulan: Pengembangan KPH dari T. javanica pada HuHBV menunjukkan hasil yang baik dengan dibuktikannya bahwa HuHBV dapat bereplikasi di KPH dari T. javanica. Hal ini menunjukkan bahwa T. javanica dapat menjadi hewan model yang potensial untuk penelitian HuHBV.

Kata kunci: virus hepatitis B, kultur primer hepatosit Tupaia, T. javanica

\section{INTRODUCTION}

Hepatitis B is still a major health problem in the world. It is estimated that there are 240 million people with chronic infection of hepatitis B virus (HBV) worldwide. ${ }^{1}$ In Indonesia, The Ministry of Health's 2013 Basic Health Research survey estimated that the proportion of hepatitis was $1.2 \%$, with $\mathrm{HBV}$ as the most prevalent cause $(21.8 \%){ }^{2}$ People chronically infected with HBV can progress to chronic hepatitis, liver cirrhosis (LC), hepatocellular carcinoma (HCC) and death. HBV infection causes approximately 786,000 deaths each year from acute liver failure, LC and HCC. ${ }^{3,4}$ Treatment for chronic HBV currently cannot achieve a curative level, as all the available drugs only control virus replication and cannot eliminate HBV from the human body. ${ }^{5}$

It is imperative to conduct more researches regarding human HBV (HuHBV) in order to develop a functional cure. However, there are some obstacles, such as restricted animal models, non-permissive permanent cell lines and limited human hepatocyte resources. ${ }^{6,7}$ One animal model suitable for HuHBV is chimpanzees, but there are some difficulties in conducting research using them, including the fact that they are an endangered species, long-lived (more than 50 years) and require high costs of maintenance. ${ }^{7,8}$ Rodents are most commonly used as animal models in different kinds of studies, but it is sometimes difficult to apply the results of such studies to humans because of methodological flaws and the critical disparity between the two species, and therefore many research centers are trying to develop models using other animals. ${ }^{9}$ Recently, many studies have shown that Tupaia are suitable for the study of HuHBV. Tupaia are more closely related to nonhuman primates than rodents are based on the overall genomic profile. ${ }^{10}$ Prior studies showed that primary hepatocytes from Tupaia belangeri can be infected with HuHBV and can transiently be infected in vivo. ${ }^{11} T$. belangeri can also be chronically infected with HuHBV and display hepatic histopathological changes similar to humans with chronic $\mathrm{HBV}^{12,13}$

Tupaia belangeri are found in Bangladesh, Bhutan, Cambodia, China, Laos, Malaysia, Myanmar, Thailand and Vietnam, while T. javanica, T. chrysogaster, T. glis, T. minor, T. salatana, T. dorsalis, T. longipes, $T$. tana, T. picta, T. montana, T. splendidula, T. gracilis, T. hypochrysa and T. ferruginea originate in Indonesia. Most Tupaia in Indonesia are found on Borneo Island - only T. javanica and T. hypochrysa are found on Java Island. ${ }^{14,15} \mathrm{~A}$ previous study has shown that primary Tupaia hepatocytes (PTH) from T. javanica can be infected with orangutans HBV (ouHBV) and gibbons HBV (giHBV). This study also showed that sodium taurocholate co-transporting polypeptide (NTCP) was expressed as a receptor for HBV on the surface of infected PTH. ${ }^{16}$ This result opens up an opportunity to explore the suitability of T. javanica for in vitro and in vivo animal models for $\mathrm{HuHBV}$, as has been previously shown in T. belangeri. The purpose of this study was to develop a primary $T$. javanica hepatocyte culture and provide proof that HuHBV can replicate in these cells by measuring laboratory parameters of HuHBV replication and observing the morphological changes of PTH infected by HuHBV.

\section{METHOD}

This is an in vitro experimental study using primary Tupaia hepatocyte (PTH). In this study, we analysed the level of laboratory parameters of HuHBV replication, including qualitative $\mathrm{HBsAg}$, quantitative 
HBsAg, HBV-DNA and cccDNA. We also observed the morphological changes of PTH infected by HuHBV. The animal procedures and observation had been done in Primate Research Centre, IPB University (PRC-IPB) laboratory.

All procedures in this study were reviewed and approved by PRC-IPB Institutional Animal Care and Use Committee (IACUC, number PRC-IPB-15-B004) for the animal procedures.

Five wild adult $T$. javanica were maintained in the quarantine facility of the PRC-IPB. The procedures were performed by experienced veterinarians at the PRC-IPB. ${ }^{16}$

Tupaia were anaesthetised with ketamine $(5 \mathrm{mg} / 100$ $\mathrm{g}$ body weight, $\mathrm{BW})$ and xylazine (1 mg/100 g BW). Blood was collected by exsanguination and the livers were collected by laparotomy. The collected liver was pre-perfused with pre-perfusion media $(500 \mathrm{~mL}$ phosphate buffer saline, PBS, $2.5 \mathrm{ml}$ ethylene glycol tetraacetic acid, 1M EGTA $(5 \mathrm{mM})$ and penicillinstreptomycin $2 \%$ ), then perfused with perfusion media $(50 \mathrm{~mL}$ Dulbecco's Modified Eagle Medium, DMEM, $500 \mu \mathrm{L} 100 \times \mathrm{CaCl}_{2}, 1 \%$ collagenase) until the liver looked pale. Pre-perfusion media $(10 \mathrm{~mL})$ was injected into the liver using a $10 \mathrm{~mL}$ syringe five times (total $50 \mathrm{~mL}$ pre-perfusion media) then 10 $\mathrm{mL}$ of perfusion media was injected into the liver. Next, the liver was sliced and minced, incubated at $37^{\circ} \mathrm{C}$ for 15 minutes and centrifuged at $2000 \mathrm{rpm}$ for 15 minutes. The supernatant was removed and 10 $\mathrm{mL}$ pre-perfusion media was added. The cells were counted and $10^{5}$ cells per well were added to a 12 well tissue culture plate and to a T25 flask. Hepatocyte culture medium (HBM/CC-3199 and HCM/CC-4182 from Lonza with $20 \%$ foetal bovine serum/FBS) was added to the well and flask. The plate and flask were incubated at $37^{\circ} \mathrm{C}$ with $5 \% \mathrm{CO}_{2}$. The HuHBV used for infection was obtained from a human with chronic HBV infection, serologically positive for HBV surface antigen (HBsAg) and $\mathrm{HBV}$ e-antigen ( $\mathrm{HBeAg}$ ), and with Hepatitis B virus deoxyribonucleic acid (HBVDNA) viral load of $>5.75 \times 10^{8} \mathrm{IU} / \mathrm{mL}$. HuHBV was resuspended in HBM media, then the HuHBV suspension was added to the hepatocyte culture on day 14 when the cells reached $80 \%$ confluence. HuHBV suspension was added to each well at $10^{6} \mathrm{IU} / \mathrm{mL}$ and $5 \times 10^{6} \mathrm{IU} / \mathrm{mL}$ HuHBV suspension was added to each flask and then the incubation was conducted for 16-20 hours at $37^{\circ} \mathrm{C}$ and $5 \% \mathrm{CO}_{2}$. After the incubation period ended, the cells were washed using PBS and a culture medium was added. The second incubation was done for 24 hours at $37^{\circ} \mathrm{C}$ and $5 \% \mathrm{CO}_{2}$.

Supernatant from the plate, supernatant from the flask and cells from the plate were collected on day 2, 4, 6, 8, 10,12, 14, 16 and 18 post-infection (DPI). Qualitative HBsAg, quantitative HBsAg, HBV-DNA and cccDNA were assessed to detect HBV replication. Qualitative and quantitative HBsAg were analysed using a chemiluminescent microparticle immunoassay (CMIA). The concentration of HBV-DNA and cccDNA was measured by real-time polymerase chain reaction (PCR, m2000 Abbott RealTime HBV Assay). Data collected from the measurements were processed using Microsoft Excel.

\section{RESULTS}

Daily observations of the wells showed that Tupaia hepatocytes have a polygonal shape (Figure 1. A and B), are epithelial-like and reach $80 \%$ confluence on day 14 after isolation. After the cells reached $80 \%$ confluence, they were infected with HuHBV. After infection, there was no change in PTH shape by DPI10 (Figure 1. C and D), but starting from DPI-16 a cytopathic effect (CPE) was observed: the size of the cells was expanded, syncytia were formed up to 5 nuclei, and displayed nuclear inclusions representing viral replication compartments (Figure 1. E and F). Figure 1 also showed that the number of hepatocyte colonies decreased over time. Figure 2 showed a comparison between the normal morphology of PTH on DPI-0 and cellular changes that occurred due to the cytopathic effect of HuHBV infection on DPI-20.

Samples were collected from both flask and plate on DPI-2, -4, -6, -8, -10,-12, -14, -16 and -18. Qualitative HBsAg, quantitative HBsAg, HBV-DNA, and cccDNA were measured from the samples. On DPI-2, qualitative HBsAg, HBV-DNA, and cccDNA could be detected in samples from both flask and plate and remained positive until DPI-18, but quantitative HBsAg level was less than $0.5 \mathrm{IU} / \mathrm{mL}$ from DPI-2 until DPI- 18 .

HBV-DNA could be detected in the supernatant and the cells as early as DPI-2. The HBV-DNA underwent a spike on DPI-12 then continuously declined until DPI-18. As seen in Figure 3, the concentration of HBV-DNA was highest in the supernatant $\left(7.08 \times 10^{3}\right.$ $\mathrm{IU} / \mathrm{mL}, \mathrm{DPI}-12)$ and lowest in the cells $(<20 \mathrm{IU} / \mathrm{mL}$, DPI-12. Meanwhile, cccDNA could also be detected in the cells as early as at DPI-2 and latest at DPI-20 with fluctuations of concentration over the observation period. The highest cccDNA concentration was 4451 copies/mL on DPI-16 (Figure 4). 

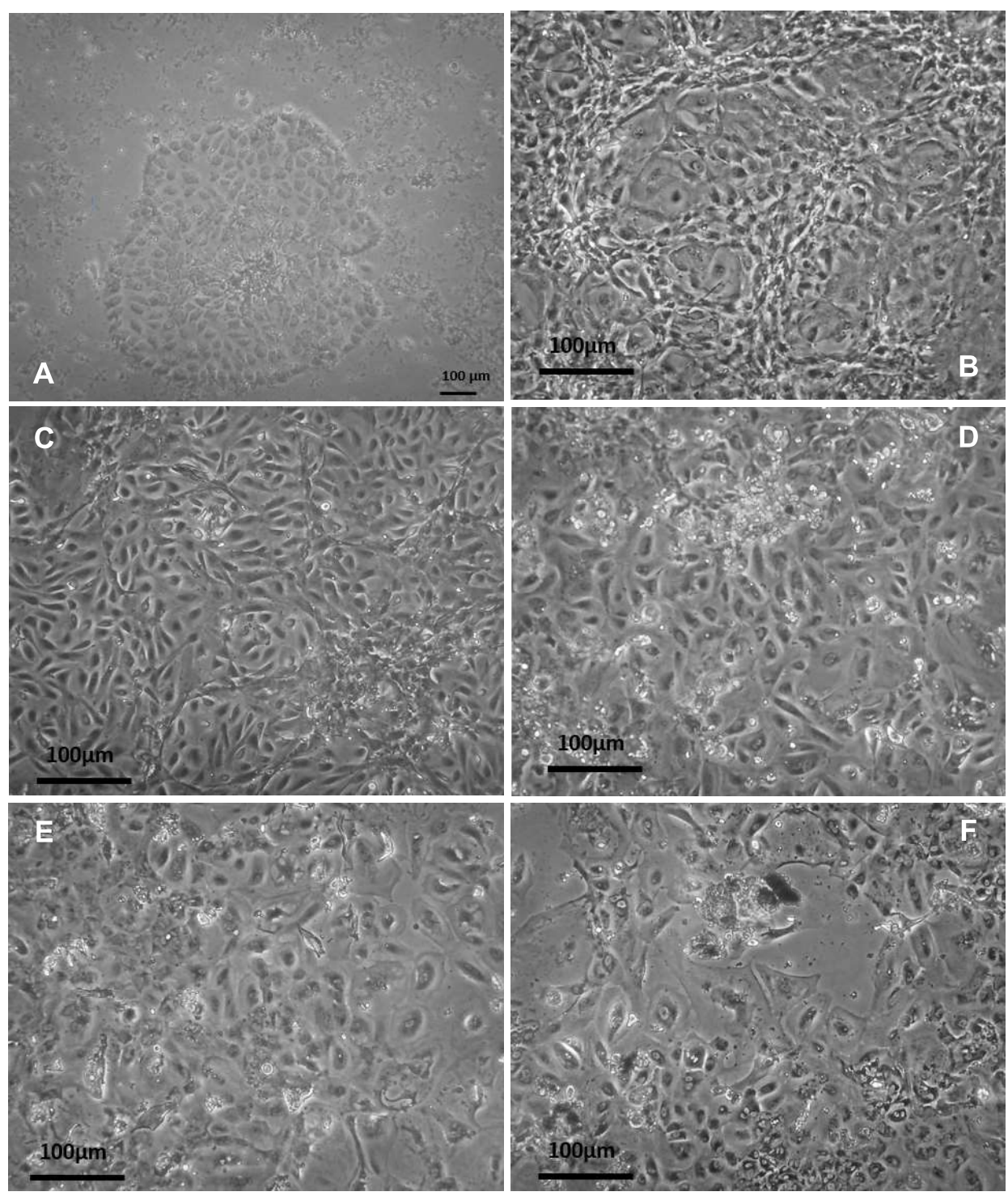

Figure 1. Primary Tupaia hepatocyte, hepatocyte colonies decreased over time. A. Culture on Day 4. B. Culture on Day 14. C. DPI-4. D. DPI-10. E. DPI-16. F. DPI-20. DPI: Days post-infection.
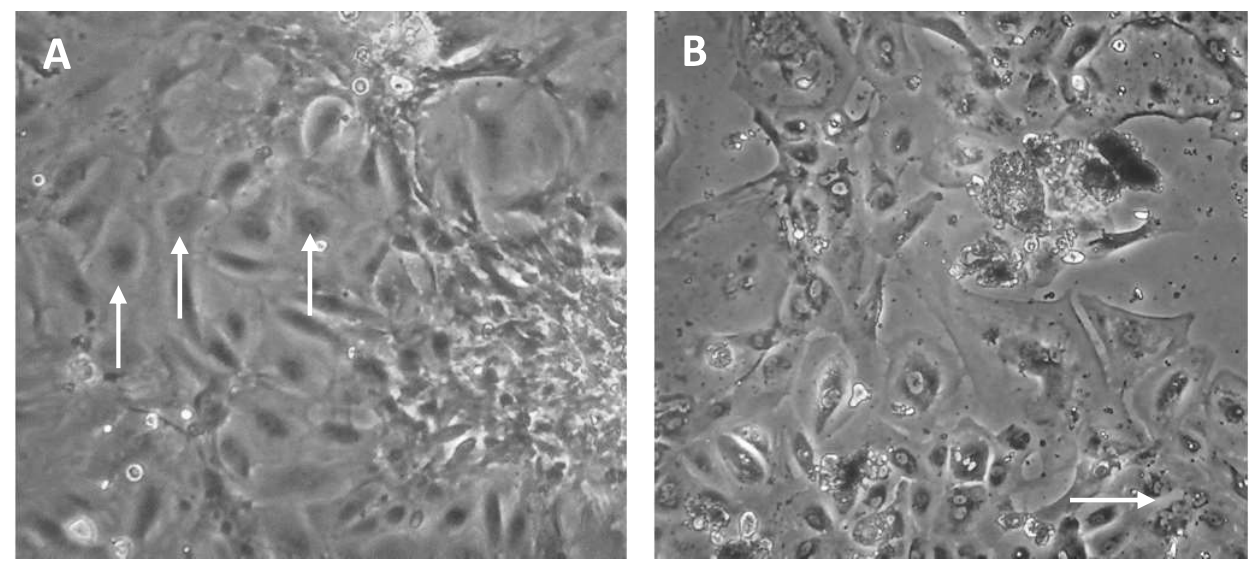

Figure 2. A. DPI-0: normal morphology of primary Tupaia hepatocytes was epithelial-like (arrow) B. DPI-20: a cytopathic effect in primary Tupaia hepatocytes showed enlarged morphology and formation of syncytia (arrow) 


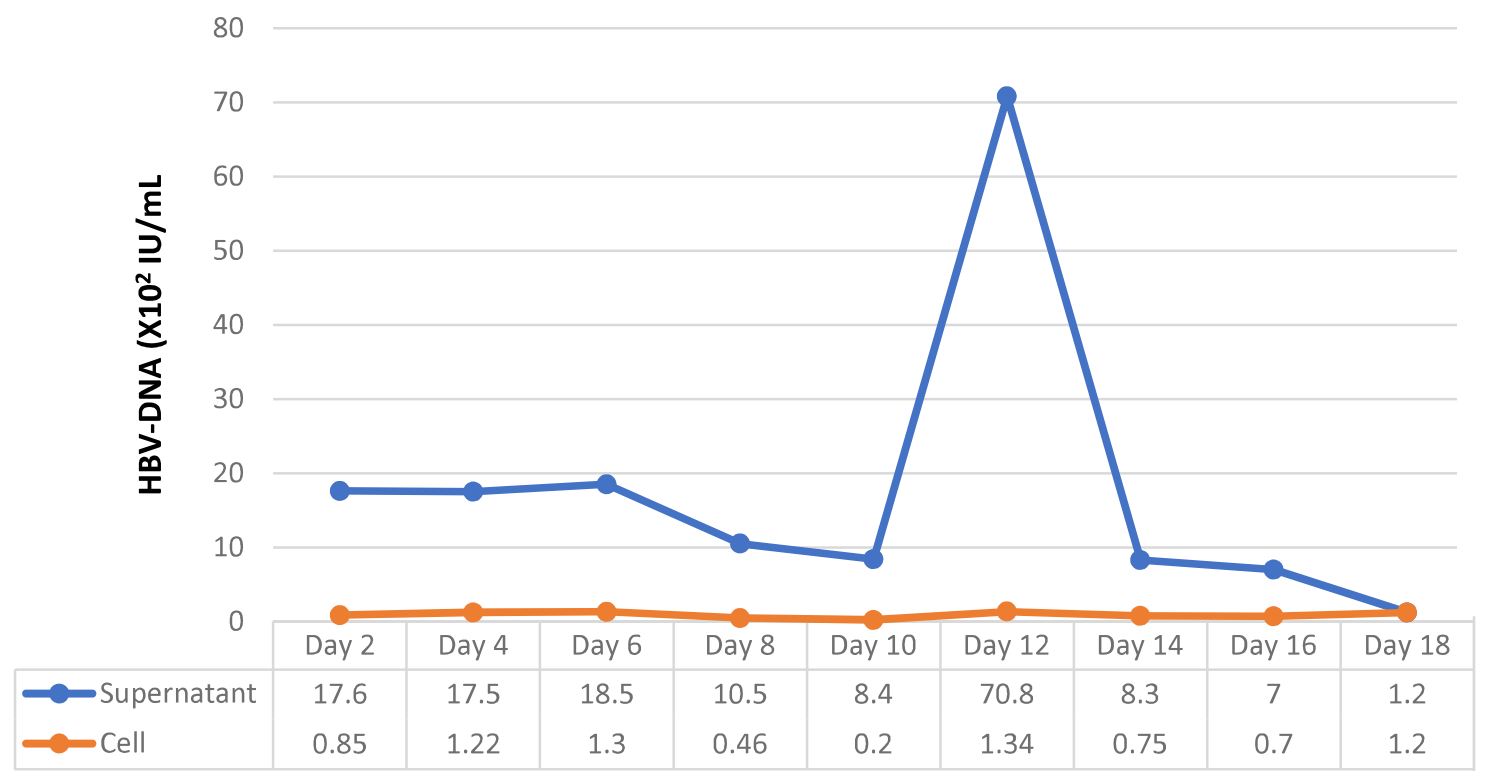

Figure 3. Time course of HBV-DNA concentration in the supernatant and cells after infection of PTH with HuHBV.

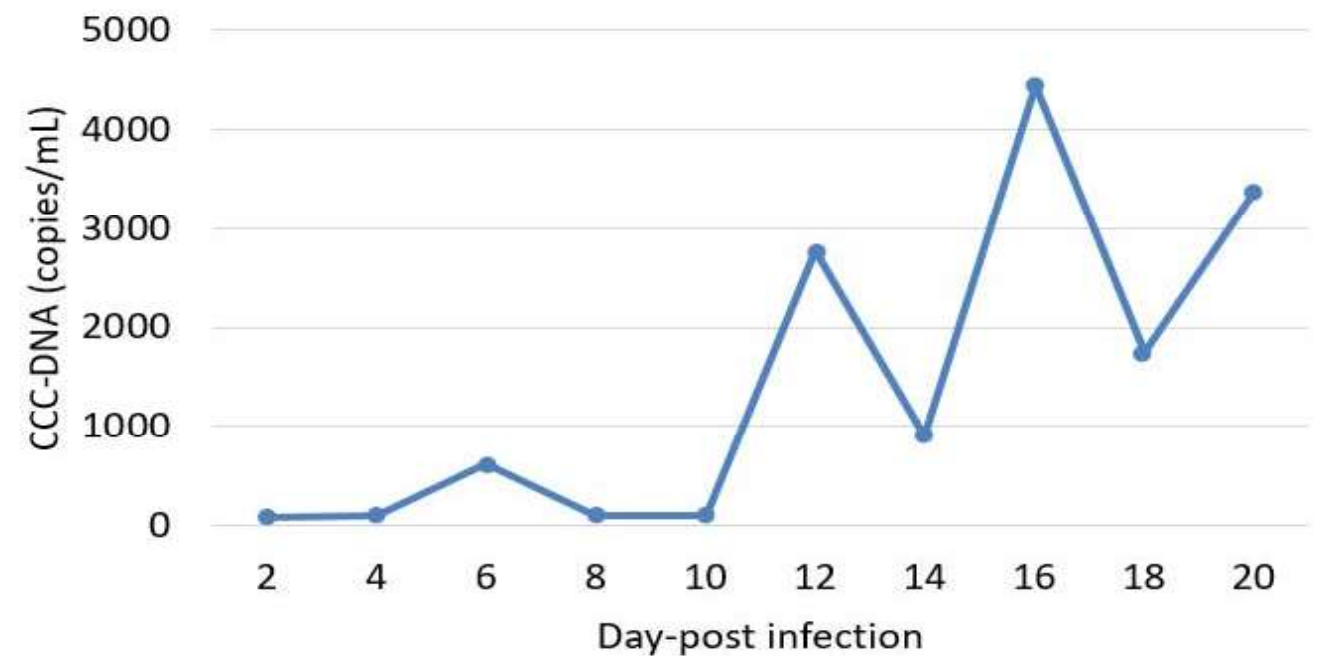

\begin{tabular}{|l|c|c|c|c|c|c|c|c|c|c|}
\hline & Day 2 & Day 4 & Day 6 & Day 8 & Day 10 & Day 12 & Day 14 & Day 16 & Day 18 & Day 2 \\
\hline $\begin{array}{l}\text { CCC- } \\
\text { DNA }\end{array}$ & 90 & 109 & 617 & 108 & 110 & 2778 & 910 & 4451 & 1746 & 3373 \\
\hline
\end{tabular}

Figure 4. Level of cccDNA post-infection of HuHBV

\section{DISCUSSION}

This study showed that PTH from T. javanica can be reproducibly infected with $\mathrm{HuHBV}$, resulting in the synthesis of HBV-DNA from hepatocytes and secretion of HBsAg and HBV-DNA to the supernatant. Furthermore, cccDNA was also detected in this study. The detection of cccDNA indicates that HuHBVinfected PTH from $T$. javanica supports cccDNA formation and intracellular amplification cycle. ${ }^{17}$

Similar to the morphology in a previous study, the PTH in this study had a polygonal shape.$^{16,18} \mathrm{CPE}$ is a cellular structural change induced by a viral infection and it can form rounding, detachment, clumping, ballooning, formation of syncytium and formation of inclusion body. The cellular structural change is detectable by light microscopy. ${ }^{19}$ In this study, CPE was detected on DPI-16 and DPI-20 (Figure 1. E and F). Prior studies showed contradicting results. One study found no morphological differences between infected PTH and uninfected PTH from T. javanica. ${ }^{16}$ Meanwhile, result from another study that used adenovirus as a vector to carry the HBV genome to 
infect PTH showed dose-dependent CPE; higher dose made CPE more macroscopically visible within the first few DPI, eventually leading to cell death. ${ }^{17}$

In the present study, HBV-DNA was detected in both cell and supernatant, meaning that the infected cell is capable of secreting the virus outside the cell. The HBV-DNA in the supernatant decreased gradually but was still detected until the end of observation on day 18 (Figure 3 ). The decrease was probably caused by limited cell proliferation capability and limited cell life span leading to cell death. Despite the gradual decline of HBV-DNA concentration in the supernatant, the HBV-DNA concentration in the cells was stable throughout the observation period. This could probably be due to reduced hepatocyte secretion capability. The other phenomenon observed was a sudden peak of HBV-DNA in the supernatant on day 12 .

In the REVEAL Study, around $60 \%$ of patients with HBsAg $(+)$ and HBeAg $(+)$ had HBV-DNA higher than $2 \times 10^{7} \mathrm{IU} / \mathrm{mL}$ and around $80 \%$ of patients with HBsAg $(+)$ and HBeAg $(-)$ had HBV-DNA less than 2 $\times 10^{4} \mathrm{IU} / \mathrm{mL} .{ }^{20}$ Having our results compared, we found significantly lower concentration in PTH, only around $10^{2} \mathrm{IU} / \mathrm{mL}$, compared to $10^{4}-10^{7} \mathrm{IU} / \mathrm{mL}$ in human hepatocytes. This could probably be caused by virions we used which came from human serum were not being purified. Human serum can interfere with HBV binding to hepatocytes, hence reducing infection multiplicity. ${ }^{21}$

We measured HBsAg and HBV-DNA as markers of HBV replication in PTH. HBsAg is a protein located on the surface of HBV which is secreted as an infectious particle or a subviral particle after HBV infects hepatocytes. HBV-DNA contains HBV genome surrounded by a nucleocapsid and a lipid membrane containing HBsAg. HBV-DNA is secreted together with $\mathrm{HBsAg}$ as an infectious particle after $\mathrm{HBV}$ infects hepatocytes. ${ }^{5}$ In the previous study using HuHBV to infect PTH from $T$. belangeri, HBsAg and viral DNA were detected until DPI-12. ${ }^{11}$ In our study, both qualitative HBsAg and HBV-DNA were detected as early as DPI-2 and persisted until DPI-18, meaning that PTH isolated from the liver of T. javanica can be infected with HuHBV and HuHBV can replicate in PTH isolated from the liver of T. javanica. The HBVDNA level in the supernatant and cells fluctuated until DPI-18, probably meaning that HBV-DNA can be detected longer in the supernatant and cells. Although the HBV-DNA was detected until DPI-18, the level of HBV-DNA was below $10^{3} \mathrm{IU} / \mathrm{mL}$, and the quantitative HBsAg level was below $0.5 \mathrm{IU} / \mathrm{mL}$, meaning that HuHBV replication in PTH remained low.
In this study we also measured cccDNA and we can detect cccDNA during the observation period. cccDNA is an episomal viral genome, stable minichromosome, act as a template for all viral transcripts, located in nuclei of infected hepatocyte and responsible for chronicity of HBV infection. The persistence of cccDNA during the observation period in our study demonstrates the stability of cccDNA inside the nuclei of infected PTH. In the end of the observation period, cccDNA tended to increase, this probably due to intrahepatocyte amplification pathway of cccDNA pool. As we know, this is the first study that demonstrates cccDNA detection inside PTH from T. javanica. This result is very promising because it will open opportunities to make T. javanica a model for HuHBV chronic infection. The study needs development in many aspects. Therefore, in the future we plan to observe the maximum duration of PTH from T. javanica after infection with HuHBV, carry out a binding study involving a receptor for $\mathrm{HuHBV}$ in PTH, enhance HuHBV replication in PTH and detect viral RNA.

\section{CONCLUSION}

In this study, we were able to develop PTH culture from $T$. javanica and it showed that HuHBV could replicate in the PTH culture. This finding supports T. javanica as a possible animal model for HuHBVrelated researches.

\section{REFERENCES}

1. Ott JJ, Stevens GA, Groeger J, Wiersma ST. Global epidemiology of hepatitis B virus infection : New estimates of age-specific HBsAg seroprevalence and endemicity. Vaccine 2012;30:2212-9.

2. Kementerian Kesehatan Republik Indonesia. Riset Kesehatan Dasar Tahun 2013. Jakarta: Kementerian Kesehatan Republik Indonesia; 2013.

3. Maclachlan JH, Cowie BC. Hepatitis B Virus Epidemiology. Cold Spring Harb Lab Press. 2015;1-12.

4. Lozano R, Naghavi M, Foreman K, Lim S, Shibuya K, Aboyans V, et al. Global and regional mortality from 235 causes of death for 20 age groups in 1990 and 2010 : a systematic analysis for the Global Burden of Disease Study 2010. Lancet 2010;380:2095-128.

5. İnan $\mathrm{N}$, Tabak F. Hepatitis $\mathrm{B}$ virus : biology and life cycle. Viral Hepat J 2015;21:1-7.

6. Weizsäcker F Von, Köck J, Macnelly S, Ren S, Blum HE, Nassal M. The Tupaia model for the study of hepatitis B virus. In: Hamatake RK, Lau JYN, eds. Methods in molecular medicine. New Jersey: Humana Press Inc.p.153-61.

7. Tsukiyama-kohara K, Kohara M. Tupaia Belangeri as an experimental animal model for viral infection. Exp Anim 2014;63:367-74. 
8. Yao YG. Creating animal models, why not use the Chinese tree shrew (Tupaia belangeri chinensis)? Zool Res 2017;38:11826.

9. Worp H van der, Howells DW, Sena ES, Porritt MJ, Rewell $\mathrm{S}$, O'Collins V, et al. Can animal models of disease reliably inform human studies? PLoS One 2017;7:1.

10. Fan Y, Huang ZY, Cao CC, Chen CS, Chen YX, Fan DD, et al. Genome of the Chinese tree shrew. Nat Commun 2013;4:1.

11. Walter E, Keist R, Niederost B, Pult I, Blum HE. Hepatitis $\mathrm{B}$ virus infection of Tupaia hepatocytes in vitro and in vivo. Hepatology 1996;24:1-5.

12. Wang Q, Schwarzenberger P, Yang F, Zhang J, Su J, Yang C, et al. Experimental chronic hepatitis B infection of neonatal tree shrews ( Tupaia belangeri chinensis ): A model to study molecular causes for susceptibility and disease progression to chronic hepatitis in humans. Virol J 2012;9:1-9.

13. Ruan P, Yang C, Su J, Cao J, Ou C, Luo C, et al. Histopathological changes in the liver of tree shrew ( Tupaia belangeri chinensis ) persistently infected with hepatitis B virus. Virol J 2013;10:1.

14. Han KH, Sheldon FH, Stuebing RB. Interspecific relationships and biogeography of some Bornean tree shrews (Tupaiidae: Tupaia), based on DNA hybridization and morphometric comparisons. Biol J Linn Soc 2000;70:1-14.

15. IUCN Red List of Threatened Species. Vol. 49, Choice Reviews Online. 2012.

16. Surya M, Iskandriati D, Mariya S, Saepuloh UUS. Primary Tupaia javanica hepatocytes culture as in vitro replication system for ape hepatitis B viruses. Microbiol Indones 2016;10:57-64.

17. Ren S, Nassal M. Hepatitis B Virus ( HBV ) Virion and covalently closed circular DNA formation in primary Tupaia hepatocytes and human hepatoma cell lines upon HBV genome transduction with replication-defective adenovirus vectors. J Virol 2001;75:1104-16.

18. Glebe D, Aliakbari M, Krass P, Knoop E V, Valerius KP, Gerlich WH. Pre-S1 Antigen-dependent infection of Tupaia hepatocyte cultures with human hepatitis B virus. J Virol 2003;77:9511-21.

19. TD, HZ. Cell culture, cytopathic effect and immunofluorescence diagnosis of viral infection. J Microbiol Mod Tech 2017;2:1-8.

20. Chen CJ, Iloeje UH, Yang HI. Long-Term outcomes in hepatitis B: the reveal-HBV study. Clin Liver Dis 2007;11:797-816.

21. Nassal M, Nelly SMAC, Baumert TF, Blum HE, Ii M. Efficient infection of primary Tupaia hepatocytes with purified human and woolly monkey hepatitis B virus. J Virol 2001;75:5084-9. 